\title{
The self-contestation of thought
}

Bryan Counter

Joseph Kuzma, Maurice Blanchot and psychoanalysis. Brill | Rodopi, 2019

Any reader of Maurice Blanchot will notice a strange dimension of his writing, a dimension less frequently remarked upon than its literary and philosophical dimensions. This other dimension of Blanchot's writing consists of a subtle gesture of, or perhaps toward, psychoanalysis. This gesture, alongside and intermixed with Blanchot's various literary and philosophical concerns, can be said to lay the foundation for his discussions of writing, inspiration, passivity, death, and the neutral, among other themes. Together, these themes make up Blanchot's unique contribution to thought, and their articulation takes place by way of a voice whose endless task is contestation, a voice that does not stop short of contesting itself.

Contestation takes many forms throughout Blanchot's work, and one major structure that it puts into question is that of the self. As Christophe Bident notes in his biography of Blanchot, even Blanchot's literary criticism, which he understood as research, tends to contain unmistakable traces of the autobiographical. ${ }^{1}$ And yet, these traces are under erasure, since the peculiar manifestation of this autobiographical tendency already puts forth a certain understanding of the self that is not only at odds with commonplace understandings but, furthermore, poses a problem for psychoanalysis. ${ }^{2}$ Furthermore, this aspect is sometimes intensified in Blanchot's book-length works. Take, for instance, the untitled post-script to The Infinite Conversation, which proclaims that, because the texts collected in the volume were "for the most part written from 1953 to 1965. . . I take them to be

\footnotetext{
${ }^{1}$ Bident writes, for instance, that "Blanchot's critical work is put together like ... a journal, with its commentaries applying first and foremost to their author. . . each 'subject' becomes the critical, invisible partner of an author who only speaks of himself via the other, the others, in the name of the others." Christophe Bident, Maurice Blanchot: A Critical Biography, 156.

${ }^{2}$ Bident continues, writing that "it is not a question of appropriating the other, but of better disappropriating oneself through the other, and of disappropriating the other through oneself." Ibid., 156.
} 
already posthumous, that is to say, regard them as being nearly anonymous." ${ }^{3}$ In other words, here, though the composition of the book is ostensibly anchored with reference to dates which would grant it a solid sense of identity by inserting it into history, the fixedness of the book and of the voice commenting on it are nevertheless challenged from within. For Blanchot, particularity and iterability are not opposed to anonymity and disappearance.

However, because Blanchot's writing already seems to implicitly engage the concerns of psychoanalysis, any study seeking to definitively place him in conversation with psychoanalytic theory should be especially careful not to simply overlay the two, to use psychoanalysis to draw out conclusions from what is implicit in his thought, or to merely restate his claims using a more explicitly psychoanalytic framework or language, "translating" Blanchot by way of psychoanalysis. Instead, a study remaining faithful first and foremost to the movement of Blanchot's thought, and thus effectively analyzing his proximity to psychoanalysis, would have to take into account the way that Blanchot problematizes the notion of translation in the first place - that is, the notion that "original" and "copy" would be viable designations or positions to take up.

Joseph Kuzma's Maurice Blanchot and Psychoanalysis is such a study. Rather than pitting Blanchot and psychoanalysis against one another, or reducing one to the other, Kuzma carefully tracks the encounter between the two by placing each of them in relation to the political dimension of Blanchot's thought. As Kuzma announces at the beginning of his introduction, "A long-overdue rapprochement between Blanchot and psychoanalysis is warranted. Without seeking to reduce the former to the latter, the time has come to allow them to speak to each other, in multiple voices, beyond reciprocity or continuity." ${ }^{4}$ It is thus a non-dialectical encounter that this book leaves open to question throughout.

Kuzma begins with Blanchot's explicit and fittingly complex treatment of politics and community. In particular, Kuzma stresses that Blanchot's absolute concern for community

\footnotetext{
${ }^{3}$ Blanchot, The Infinite Conversation, 435.

${ }^{4}$ Joseph Kuzma, Maurice Blanchot and Psychoanalysis, 1. Hereafter, parenthetical citations refer to this text.
} 
requires a heightened vigilance, as is seen in "the highly-idiosyncratic form of 'communism' which Blanchot, from 1968 onward, thus espouses," a communism radically open to otherness, that "would partake in no lineage, heritage, or tradition. . . a communism without communism" (14). Kuzma thus finds in "Blanchot's mature, political thought" the radical contestation and suspension of "the philosophical, theological, and psychological presuppositions" inherent in any dominant political sensibility (15). In this context, "Blanchot sees psychoanalysis as a rather efficacious means for opening man up to a relation with radical otherness - beyond all recuperation, beyond all reason" (15).

By marking Blanchot's point of contact with psychoanalysis primarily in terms of a certain movement inherent in his thought, rather than strictly thematic content, Kuzma establishes a threefold object of analysis: Blanchot's thought, the interaction between Blanchot's thought and psychoanalysis, and psychoanalysis. The guiding thesis of Kuzma's book, then, is twofold. First, Kuzma wants to show that there is a psychoanalytic core to Blanchot's thought, though one that is often latent. Second, following Blanchot's lead, he argues that, if psychoanalysis is to remain relevant to the many fields among which it circulates, it must take up the spirit of contestation as unrelentingly as would the community-to-come described by Blanchot. Above all, psychoanalysis must always take care to intervene and reorient itself when it begins to display a thirst for mastery and a tendency to become an institution. For, as Blanchot himself asks, "How can one hope to reconcile a psychoanalysis that always puts one into question (questioning the very place one occupies as an observer or thinker, knowing or speaking) and a psychoanalysis that suddenly takes itself to be the naively absolute affirmation of a scientifically certain knowledge that would explain an objectively determined reality?" ${ }^{5}$ It is with this incisive question in mind, quoted by Kuzma in the first chapter, that the study proceeds.

In Chapter 1, Kuzma carefully reads two versions of an essay by Blanchot, published thirteen years apart - in 1956 as "Freud," and reworked for publication in The Infinite

\footnotetext{
${ }^{5}$ Blanchot, The Infinite Conversation, 234-235.
} 
Conversation (1969) as "The Speech of Analysis." While both iterations of this essay provide insight into Blanchot's take on psychoanalysis, Kuzma's comparison of the two versions sets them against the backdrop of a significant change in the status of psychoanalysis in France, which goes along with the contestation of virtually every aspect of French society, politics, and philosophy. The 1969 edition of the article centers around the suggestion that Freud, in his self-contestation, may have discovered plural speech, a non-dialectical speech that "would maintain the movement of difference without reducing it to some form of identity" (36). According to Blanchot, plural speech would "affirm interruption and rupture" in order to express and maintain difference through dialogue, ${ }^{6}$ a task that resonates with the project of psychoanalysis. If this is indeed the contribution of Freud - and psychoanalysis - then it becomes possible to rephrase Blanchot's question, quoted above. If Freud's discovery makes possible a new kind of speech, a speech that "remains ... outside the dialectical pairings which seek to generate unity through plurality, and identity through difference" (36), then how can repeated attempts to institutionalize and codify psychoanalysis lead to anything but a betrayal of this speech, a betrayal of psychoanalysis itself? And, at the same time, if plural speech is entirely different from established language and meaning, and if plural speech marks the possibility of a new relation, how can psychoanalysis harness plural speech and make use of it in a rigorous fashion, without falling back into a dialectical relation?

For Blanchot, psychoanalysis is threatened as a result of this tension, and exhibits a tendency to decide in favor of unity and totality, thus squandering its greatest insights. However, this sliding of psychoanalysis toward its own dissolution in the formation of institutional structures has, in a sense, always already happened. Any "beginning" of the danger posed to psychoanalysis would be inseparable from the very inception of psychoanalysis. For psychoanalysis "must be called upon to refuse not only the institutionalizing and formalizing tendencies of late capitalism and bourgeois culture, but also those of psychoanalysis itself. It must be called upon to contest and interrogate itself

${ }^{6}$ Ibid., 82. 
in a manner that is unsparing, relentless" (60). Kuzma notes that, in the 1969 version of the essay, Blanchot portrays Lacan "as using dialectics to put dialectics into question," whereas in the 1956 version Blanchot "still appears to situate Lacan within the general economy of Hegelian thought" (55). However, if the shift from the earlier to the later version of the essay attributes greater radicality to both Freud and Lacan, Blanchot's misgivings about psychoanalysis are also made more explicit, as if the necessarily precarious nature of the psychoanalytic project had become more apparent to him. In the later version, for instance, Blanchot revises a sentence calling psychoanalysis "at once a technique and a knowledge: a power, an action, and a comprehension," inserting the qualification that this is true "always within the horizon of science." Along with Blanchot's increasing recognition of the radical potential of psychoanalysis, then, comes his awareness that this potential is never guaranteed, but is always under threat of immense danger, the danger of becoming "an objective science replete with a codified technique of its own and a determinate object of inquiry" (59). As Kuzma wonders, "Is psychoanalysis, then, to be affirmed? Perhaps. But only in the form of what we might call a "psychoanalysis without psychoanalysis"' (60).

Keeping these concerns in mind, Kuzma moves through the remaining chapters of the book, providing a thorough account of how Blanchot's various texts interact with psychoanalytic thought, as well as an account of the context in which they - both Blanchot's texts and the psychoanalytic ideas to which they respond - were developed. And, of course, it is not only with Freud or Lacan as interlocutors that Kuzma develops this analysis. For instance, through particularly compelling readings of Blanchot's evolving conception of madness in relation to Hölderlin's creative trajectory, as well as what Philippe LacoueLabarthe calls Blanchot's attempt "to destroy... the conventional conception of narcissism,"8 Kuzma highlights the intersection of this encounter with the literary, which Blanchot often turns to in order to elucidate the logic of the phenomenon in question. In response to Jean

\footnotetext{
7 Blanchot, "Freud," 496; The Infinite Conversation, 455.

${ }^{8}$ Philippe Lacoue-Labarthe, "Interview with Pascal Possoz," in Ending and Unending Agony: On Maurice Blanchot, 106.
} 
Laplanche's and Jacques Derrida's criticisms that accuse Blanchot of reducing and essentializing madness in favor of poetry, Kuzma contends that, if essence means "something like an indispensable or fundamental property, then it is by no means the essence of madness that is being fixed or predetermined. . . but rather, the essence of a certain poetic task - a task which draws the poet dangerously into relation with his requisite dissolution" (79). This dissolution is brought into play once again with the consideration of narcissism and the Narcissus myth, with which Blanchot hopes to hold open the indeterminacy and danger that are imposed upon Narcissus. In other words, it is not only that Blanchot aims to destroy a "cultural narcissism." Instead, by making narcissism "invincible, invulnerable to criticism or . . inevitable,"9 he emphasizes the aspect of narcissism which resists the unification or gathering that takes place in popular accounts of Narcissus. As Kuzma puts it, "Unknown to himself and others, Narcissus is precisely not the Narcissus of traditional narcissism. He is someone anonymous, impersonal, neutral. He is someone as yet undetermined" (109-110). He is, as Blanchot calls him, "anti-Narcissus," the poet "who, through poetry, bears witness to the impossibility of narcissism" (111).

By way of engagements with Serge Leclaire, Jean Laplanche, D. W. Winnicott, Emmanuel Levinas, André Green, and Julia Kristeva, among others, the remaining chapters examine the status of the primal scene, responsibility, and the maternal in Blanchot's thought. Through a reading of "(A primal scene?)" in The Writing of the Disaster, Kuzma emphasizes Blanchot's insistence on "the impossibility of establishing a master frame, or a master scene" (135) and his criticism of the quest for the origin undertaken by Freud and psychoanalysis: "If Freud's discourse operates under the presupposition that the primal, pathogenic event really happened to a self, then Blanchot wants to ask the question of what precedes (and ultimately conditions) the installation of this self. If Freud, moreover, assumes that the primal scene is an event that really occurred at a specific moment in history, then Blanchot wants to ask questions about what makes history, and time itself, possible in the

\footnotetext{
${ }^{9}$ Blanchot, The Writing of the Disaster, 61.
} 
first place" (146). By pulling apart the major terms of psychoanalysis - always in relation to another kind of thought, whether it be political, philosophical, or literary - Blanchot points to a profoundly psychoanalytic basis for thought, which lies before, beyond, or outside of the thought of psychoanalysis. It is only by opening itself to such a basis that psychoanalysis could be a "psychoanalysis without psychoanalysis," a thought capable of withstanding its own extensive critique.

Thus, through a close reading of the exchanges between Blanchot's thought and psychoanalysis, Kuzma's book also offers a close reading of the movements that occur within each. On the one hand, we see that Blanchot's thought always puts itself into question through a ceaseless contestation; and on the other hand, we see that the various developments in psychoanalysis, the various disputes between the thinkers and sects of the field, can be understood, in a certain light, precisely as the movement of thought contesting itself, caught between the demands of radical openness and systematization. This is the way in which Kuzma "allow[s] them to speak to each other, in multiple voices, beyond reciprocity or continuity" (1).

This book will be of interest both to those who wish to better understand the development and tendencies of Blanchot's thought, particularly in a psychoanalytic context, and those who are interested in the relationship of psychoanalytic thought to itself and to other forms of thought. Thorough and well-researched throughout, Maurice Blanchot and Psychoanalysis is potentially marred only by the absence of a stand-alone conclusion, which leads to an ending that feels somewhat hasty. However, though this conclusion does not return directly to the book's opening claims, it does return to many of the preceding chapters' major concerns, from the trauma of responsibility, to the primal scene, to the possibility and impossibility - of narcissism. By ending with a brief gloss of the "primal scene" in The Writing of the Disaster, Kuzma concludes his study with an insightful and provocative gesture, and perhaps a nod to the "interruption and rupture" necessary for plural speech to occur. "(A primal scene?)" is one of Blanchot's most profoundly "psychoanalytic" texts, and its status 
remains ambiguous to this day - it can be read as a literary, psychoanalytic, philosophical, or autobiographical text, and yet cannot with any certainty be classified as any one of these, for several reasons acknowledged by Kuzma. This ambiguity, which entails both a general uncertainty and the admixture of several discourses at odds with one another, is what grants "(A primal scene?)" its privileged place in Blanchot scholarship and its endless fascination for and by psychoanalytic thought. At the heart of this ambiguity are the questions articulated by Kuzma: "In which sense is the scene in question really primal? To what extent is it even a scene? The questions seem to ramify without resolution, destabilizing not only the fragment itself, but the book within which it appears" (133). It is this line of questioning, prompted by the fragmentary scene itself, that Blanchot - and Kuzma - call for in the psychoanalytic context.

@2021 Bryan Counter

\section{References}

Bident, Christophe. Maurice Blanchot: A Critical Biography. Translated by John McKeane. New York: Fordham University Press, 2019.

Blanchot, Maurice. “Freud." La Nouvelle Revue française, vol. 45, September 1956, 484-496.

- - . The Infinite Conversation. Translated by Susan Hanson. Minneapolis: University of Minnesota Press, 1993.

- --. The Writing of the Disaster. Translated by Ann Smock. Lincoln: University of Nebraska Press, 1995.

Kuzma, Joseph. Maurice Blanchot and Psychoanalysis. Leiden: Brill | Rodopi, 2019.

Lacoue-Labarthe, Philippe. Ending and Unending Agony: On Maurice Blanchot. Translated by Hanes Opelz. New York: Fordham University Press, 2015. 